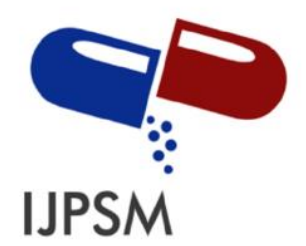

Manoj Kumar et al, Int. Journal of Pharmaceutical Sciences and Medicine (IJPSM),

Vol.6 Issue. 1, January- 2021, pg. 51-74

ISSN: 2519-9889

Impact Factor: 3.426

\title{
Exploring an Indian Herb Sphaeranthus indicus for Antimicrobial Efficacy against Helicobacter pylori and Effect of Combination Therapy against Drug Resistant Human Pathogens
}

\author{
Manoj Kumar ${ }^{1}$; Prachi Goyal ${ }^{2}$; Zafar Mehmood ${ }^{3}$; Prateek Sharma $^{4}$; Rajashree Das ${ }^{4}$; \\ Kunal Das ${ }^{5}$; Shweta Mahant ${ }^{4}$ \\ ${ }^{1} \mathrm{PhD}$ Student, Department of Microbiology, Maharaj Vinayak Global University, Jaipur, Rajasthan, India \\ ${ }^{2}$ Assistant Professor, Maharaj Vinayak Global University, Jaipur, Rajasthan, India \\ ${ }^{3}$ Department of Microbiology, The Himalaya Drug Company, Dehradun, Uttarakhand, India \\ ${ }^{4}$ Amity Institute of Biotechnology, Amity University, Noida, Uttar Pradesh, India \\ ${ }^{5}$ HOD and Consultant, Gastrointestinal Sciences, Manipal Hospital, Delhi, India \\ DOI: 10.47760/ijpsm.2021.v06i01.005
}

\author{
Corresponding Author: \\ Dr Prachi Goyal, PhD \\ Assistant Professor, \\ Maharaj Vinayak Global University, \\ Jaipur, Rajasthan, India \\ E-mail: prachigoyal458@gmail.com \\ Phone Number: +919680309450
}

Financial disclosure:

Nil

Conflict of interest:

None

Abstract: Among the various opportunistic infections, those caused by Helicobacter pylori, a human Opportunistic pathogen, is attracting much attention. Relatedly, increasing rates of antibiotic-resistant $\boldsymbol{H}$. pylori strains have been found, and therefore, the search for new eradication strategies and effective antibiotic therapies has become an issue of crucial importance. Hence, research effort is focused on exploring an Indian Herb as sources of anti- $\mathrm{H}$. pylori agents. The antibacterial activity of flower extract of Sphaeranthus indicus has been evaluated against clinical isolates of $\boldsymbol{H}$. pylori. The plant- also has been found to be effective against a variety of human pathogens. Initial antibacterial screening was made by the disc diffusion method. The results presented in this work demonstrated that among the plant preparation analyzed, the flower extract of $S$. indicus was capable of inhibiting the in vitro growth of $H$. pylori. New sources of antimicrobial drugs -are now needed to be identified and improved strategy should be developed to combat multidrug resistance problem in pathogenic bacteria. Plant extract and phytochemicals demonstrating antimicrobial action needs to be exploited for their synergistic action between extracts with antibiotics to exploit it in modern phytomedicine and combinational therapy. In the present study in addition to $\mathrm{H}$. pylori the alcoholic extracts of Sphaeranthus indicus was screened for their antimicrobial efficacy against a wide variety of drug resistant bacteria and yeast. The extracts showed promising action against one or more drug resistant bacteria as well as against Candida albicans with MIC ranged from $0.5 \mathrm{mg} / \mathrm{ml}$ to $4.62 \mathrm{mg} / \mathrm{ml}$. The combination of the extract showed synergistic action. 


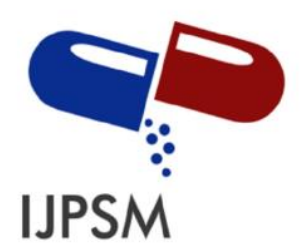

Manoj Kumar et al, Int. Journal of Pharmaceutical Sciences and Medicine (IJPSM), Vol.6 Issue. 1, January- 2021, pg. 51-74

ISSN: 2519-9889

Impact Factor: 3.426

The extract of Sphaeranthus indicus exhibited synergy with antibiotics, tetracycline, chloramphenicol, ampicillin and gentamicin against methicillin resistant $S$. aureus which has indicated their potential to be exploited in combination drug therapy after careful evaluation in vivo model.

Keywords: Helicobacter pylori; anti-Helicobacter; medicinal plant; plant extract; phytochemical; antimicrobial; Sphaeranthus indicus;__Synergistic action

\subsection{Introduction}

Helicobacter pylori is a Gram-negative spiral-shaped bacterium that was first isolated by Barry Marshall and J. Robin Warren. Since its discovery in 1983, the microorganism has been associated with the etiopathogenesis of several diseases of the digestive system, such as gastritis, peptic ulcer disease and gastric cancer. ${ }^{1}$ Conventional treatment for eradication therapy of these infections is mainly based on the use of multiple drugs, such as clarithromycin, amoxicillin, furazolidone, tetracycline and metronidazole with bismuth or a proton pump inhibitor. ${ }^{2}$

Although the conventional treatment for eradication therapy of $H$. pylori allows obtaining high cure rates, eradication failure rate remains of 5-20\%. This fact may be partially explained by non-compliance in some patients who do not follow the treatment properly and by the development of resistance to antibiotics used. ${ }^{3}$ The prevalence of dual resistance and multidrug resistances has increased significantly in many countries which has become a major obstacle in eradicating the H. pylori infection (gehlot et al 2016, Gehlot et al 2016, Mahant et al 2018, Mahant et al 2019)._Therefore, there is a growing need to search new therapeutic agents that can hopefully eradicate this significant human pathogen and medicinal plants are a useful source of novel drugs. Several natural products have demonstrated antibacterial activity against H. pylori ${ }^{4}$ (Saumya et al 2020, Gehlot 2016, Shilpi 2014) and for centuries a wide variety of plants and substances derived from plants have been used to treat gastrointestinal disorders.

Ayurveda, the oldest traditional system of India, reveals that ancient Indians had a rich knowledge of medicinal value of different plants. India has been endowed with a very rich flora owing to the extreme variations in climate and geographical conditions prevalent in the 


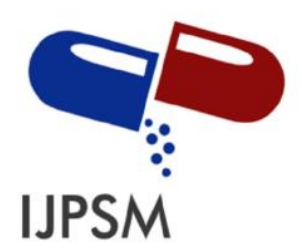

Manoj Kumar et al, Int. Journal of Pharmaceutical Sciences and Medicine (IJPSM), Vol.6 Issue. 1, January- 2021, pg. 51-74

ISSN: 2519-9889

Impact Factor: 3.426 country. With the advent in science, many of the crude drugs used in traditional system have been investigated scientifically. Sphaeranthus indicus Linn. is widely used in Indian traditional system of medicine for curing various ailments. ${ }^{5}$ It grows in rice fields, dry waste places and cultivated lands in tropical parts of India. It is distributed throughout India, Sri Lanka, Africa and Australia from sea level to $1200 \mathrm{~m}$ altitude. $^{6}$

The use of herbal and other natural substances is part of the fabric of traditional medicine in different part of the world. Medicinal plants have been found good source of therapeutic and novel compounds. Targeted screening of a large diversity of medicinal plants is expected to yield novel biological activities including problematic group of multidrug resistant bacterial pathogens ${ }^{10}$.

Bacteria have evolved numerous defenses against antimicrobial agents and drug resistant pathogens are on the rise and such bacteria have become a global health problem. Nearly twenty years ago over $90 \%$ Staph. aureus strains were reported $\beta$ lactamase positive. Strains of $\beta$-lacatam resistant Staphylococcus aureus including MRSA now pose a serious problem to hospitalized patients and their care providers ${ }^{11}$. The production of $\beta$-lactamase is recognized as one of the main mechanism of bacterial-resistance to $\beta$-lactamase antibiotics. Numerous compound have been included in the list of $\beta$-lactamase inhibitors and some of these have shown potential clinical usefulness based on their synergistic-effects when they are combined with $\beta$-lactamase-labile antibiotics. Many $\beta$-lactamase were found to be resistant to $\beta$-lactamase inhibitors. Similarly multidrug resistant problem is common in members of family Enterobacteriaceae specially E.coli, Salmonella, Shigella and several other humans and animal pathogen like Haemophilus influenza, Campylobacter, Pseudomonas aeruginosa, Mycobacterium tuberculosis both in developing and developed countries ${ }^{12}, 13,10$. 


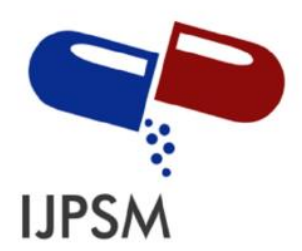

Manoj Kumar et al, Int. Journal of Pharmaceutical Sciences and Medicine (IJPSM), Vol.6 Issue. 1, January- 2021, pg. 51-74

ISSN: 2519-9889

Impact Factor: 3.426 India has one of the world's richest flora with about 120 families of plant comprising 1, 30,000 species. A large portion of the world population especially in the developing countries depends on the traditional-system of medicine for a variety of diseases. The world health organization (WHO) reported that $80 \%$ of the world's population rely chiefly on traditional medicines and major part of the traditional therapies involve the use of plant extracts or their active constituents ${ }^{14}$.

According to an estimate about 119 secondary plant metabolites are used globally as drugs. It has been estimated that $14-28 \%$ of higher plant species are used medicinally, that only $15 \%$ of all angiosperms have been investigated chemically and that $74 \%$ of pharmacologically active plant derived components were discovered after following upon ethanobotanical use of plants ${ }^{15}$. The plants are valuable in the three basic ways: (1) they are used as source of direct therapeutic agent. (2) As a source of new bioactive metabolites including antimicrobial, antihelminthic and antiprotozoan etc. (3) they serve as raw material base for elaboration of more complex semisynthetic chemical compounds.

Concerted efforts have been made all over the world to explore the various biological and specific pharmacological activities and their active compounds all over the world. The antibacterial and antifungal activities of Indian medicinal plants are widely known against a variety of pathogenic and opportunistic microorganisms 16. However, targeted screening with improve strategy to evaluate the efficacy of various potential plants against problematic multi drug resistant bacteria is in the stage of infancy.

It is expected that plant extract showing target sites other than those used by antibiotics will be active against drug resistant microbial pathogens. However very little information is available on such activity of plant extract. In the recent years plants have been screened against multidrug resistant bacteria including Staphylococcus aureus, Salmonella paratyphi, Escherichia coli, Shigella dysentriae and Candida albicans. The 


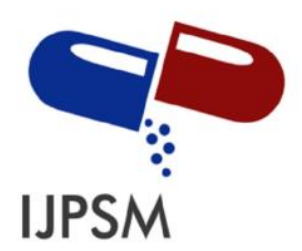

Manoj Kumar et al, Int. Journal of Pharmaceutical Sciences and Medicine (IJPSM), Vol.6 Issue. 1, January- 2021, pg. 51-74

ISSN: 2519-9889

Impact Factor: 3.426

selection of medicinal plant was based on their traditional uses in India and reported antimicrobial activity of many medicinal plants ${ }^{17,18}, 19$.

The recent development in the phytopharmacology is development of multicombinational drug against multidrug resistant bacteria. This has been possible due to interaction among plant extracts (Phytocompounds) and with other chemotherapeutic agents that may be synergistic or additive in their interaction. The development of these drugs has grown a new future in the area of phytopharmacology and medical practices.

At present multi drug therapy or combinational antibiotic therapy is in use. However its efficacy may be severely hindered against several MDR bacteria. Therefore, there is an increased request to develop novel drugs against multi drug resistant bacteria. One possible approach is to screen/unexplored Indian medicinal bioactive plant extracts for their potential to be used against multi drug resistant bacteria.

Considering the vast potential of Indian medicinal plants as an anti-infective agent, we have selected Sphaeranthus indicus on the basis of their traditional uses, ethanopharmocoloical data and local availability. The present screening programme has been planned to identify the antimicrobial efficacy of S.indicus against drug resistant microbial pathogens and to assess synergy with antibiotics in vitro.

\subsection{Material and Methods}

\subsection{Collection and Authentication of Plant Material}

The plant material was purchased from ayurvedic raw drug store, Haridwar, Uttarakhand. The purchased plant material and fresh plant was collected, and authenticated at Patanjali Herbal laboratory, Haridwar, Uttarakhand. Crushed powders of Flowers were successively Soxhlet extracted. Later, each of the homogenates was filtered and the residue was reextracted twice for complete exhaustion, the extracts were cooled individually. Each filtrate 


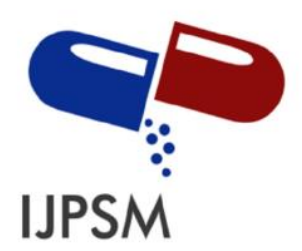

Manoj Kumar et al, Int. Journal of Pharmaceutical Sciences and Medicine (IJPSM), Vol.6 Issue. 1, January- 2021, pg. 51-74

ISSN: 2519-9889

Impact Factor: 3.426 was concentrated to dryness in vitro and re dissolved in respective solvents, were stored at $4^{\circ} \mathrm{C}$ in a refrigerator, until screened for phytochemical activity.

\subsection{GC-MS analysis}

One gram of sample was extracted in $100 \mathrm{ml}$ of diethyl ether using Soxhlet apparatus and the extract was concentrated to dryness under vacuum. GC-MS analysis of the diethyl ether extract of the selected drugs was carried out on a 5975C Agilent system equipped with a DB$5 \mathrm{~ms}$ Agilent fused silica capillary column $(30 \times 0.25 \mathrm{~mm}$ ID; film thickness: $0.25 \mu \mathrm{m})$, operating in electron impact mode at $70 \mathrm{eV}$. Pure helium (99.9995\%) was used as carrier gas at a constant flow of $1.5 \mathrm{~mL} / \mathrm{min}$ and an injection volume of $1 \mu \mathrm{L}$ was employed (split ratio is 10:1). Mass transfer line and injector temperature were set at $230^{\circ} \mathrm{C}$ and $250^{\circ} \mathrm{C}$, respectively. The total running time for $\mathrm{GC}$ was 35 min. Mass spectra was taken at $70 \mathrm{eV}$; with a scan range $40-700 \mathrm{~m} / \mathrm{z}$. Solvent cut time was $3 \mathrm{~min}$; MS start time being $3 \mathrm{~min}$; MS end time being $35 \mathrm{~min}$; Ion source temperature set to $230^{\circ} \mathrm{C}$ and interface temperature being $240^{\circ} \mathrm{C}$.

\subsection{Screening of crude extracts for anti-H. pylori activity}

Antimicrobial activities of different extracts were evaluated by the agar well diffusion method, and zone of inhibition was calculated. H. Pylori inocula prepared at McFarland's turbidity standard 4 was plated onto Brain heart infusion (BHI) agar. The inoculate was evenly spread on the plate from subcultures of bacteria by sterile cotton swab and allowed to dry for 5-8 $\mathrm{min}$. Wells (6 $\mathrm{mm}$ in diameter) were punched into the agar using a sterile stainless-steel borer and filled with different concentration such as 10, 20, 50, and $100 \mu \mathrm{L}$ of the extract. Methanol was used as a negative control. The plates were incubated under microaerophilic conditions at $37{ }^{\circ} \mathrm{C}$ for 72 hours after which the diameters of zones of inhibition were measured in millimetres. The experiment was repeated once and mean zones recorded. 


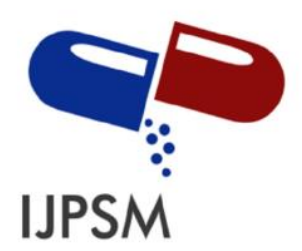

Manoj Kumar et al, Int. Journal of Pharmaceutical Sciences and Medicine (IJPSM), Vol.6 Issue. 1, January- 2021, pg. 51-74

ISSN: 2519-9889

Impact Factor: 3.426

\subsection{Screening of $S$. indicus for anti-H. pylori activity by Disc diffusion assay}

The isolated strains of $H$. pylori from patients who were suffering from different gastroduodenal diseases were found dual-drug resistant, were chosen for antibacterial activity of $S$. indicus extracts in different solvents such as aqueous, and methanol. The bacterial culture was suspended in $5 \mathrm{~mL}$ of sterilized $0.85 \%$ phosphate buffer saline (PBS). The feculent bacterial suspension was makeup by comparing with McFarland's turbidity standard 4 and inoculum was equally spread on the BHIA plate. The Whatman filter paper disc was sterilized and loaded with various concentrations of aqueous and methanol extracts of S. indicus. Aqueous and methanol were used as a negative control. The plates were observed under microaerophilic conditions $\left(85 \% \mathrm{~N}_{2}, 10 \% \mathrm{CO}_{2}\right.$, and $\left.5 \% \mathrm{O}_{2}\right)$ at $37^{\circ} \mathrm{C}$ and zone measured after 72 hours. Every test was performed in triplicates and repeated once also.

\subsection{Drug resistant and sensitive bacterial strains used in the screening programme}

The Standard strains were obtained from different National and International Culture Collection Centers/ Collection of individual scientist and clinical isolates were collected from Department of Microbiology, Patanjali Research Centre Haridwar U.K.. Multidrug resistant bacteria include the strains of Shigella, Salmonella typhi, Staphylococci including methicillin resistant Staphylococcus aureus (MRSA), Psuedomonas aeruginosa and R-plasmid harbouring strains of E. coli. MRSA and some other Gram positive and Gram negative bacteria were also used in our laboratory. The details of the test strains and their relevant characteristics are mentioned in Table 7.

\subsection{Chemicals and Antibiotics}

All the antibiotic discs were purchased from Hi-Media Lab Pvt Ltd, Mumbai, India. The indicator dye p-iodonitro tetrazolium violet were purchased from Sigma Chemical Co., USA. MMS and Sodium azide were purchased from Sisco Reseach Laboratory, India. All the other media/chemicals used were of analytical grade. 


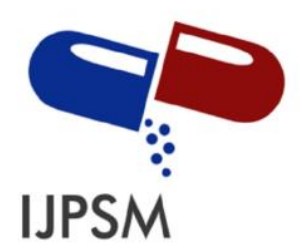

Manoj Kumar et al, Int. Journal of Pharmaceutical Sciences and Medicine (IJPSM), Vol.6 Issue. 1, January- 2021, pg. 51-74

ISSN: 2519-9889

Impact Factor: 3.426

\subsection{Bacterial cultures}

Bacterial isolates were obtained from different sources and were subjected to antibiotic sensitivity by disc diffusion, method ${ }^{20}$.

\section{8. ß-lactamase production}

The method described earlier ${ }^{10}$ was used for detection of production of ß-lactamase.

\subsection{Culture Media and Inoculum preparation}

Nutrient broth/ Agar and Muller-Hinton broth/ agar (Hi-Media Pvt. Ltd., Mumbai, India) were used to grow the test bacteria at appropriate temperature $30-37{ }^{\circ} \mathrm{C}$ for $18 \mathrm{hrs}$ and then appropriately diluted in sterile $0.8 \%$ saline solution to obtain a cell suspension of $10^{5}-10^{6}$ $\mathrm{CFU} / \mathrm{ml}$.

\subsection{Preparation of plant extracts and its fractionation}

Plant extract was prepared as described earlier ${ }^{21}$ with a little modification. 800 gram of dry, plant powder was soaked in 2.5 liter of 70\% ethanol, for 8-10 days and stirred after every 10 $\mathrm{hr}$ using a sterilised glass rod. At the end of extraction, it was passed through Whatman filter paper No.1 (Whatman Ltd., England). This alcoholic filtrate was concentrated under vacuum on rotary evaporator at $40{ }^{\circ} \mathrm{C}$ and then stored at $4{ }^{\circ} \mathrm{C}$ for further use. The crude extract was prepared by dissolving known amount of the dry extract in DMSO, to have a stock solution of $100 \mathrm{mg} / \mathrm{ml}$ concentration.

\subsection{Antimicrobial assay}

The agar well diffusion method ${ }^{25}$ as adopted earlier was used. $0.1 \mathrm{ml}$ of diluted inoculum $\left(10^{5} \mathrm{CFU} / \mathrm{ml}\right)$ of test organism was spread on Muller-Hinton agar plates. Wells of $8 \mathrm{~mm}$ 


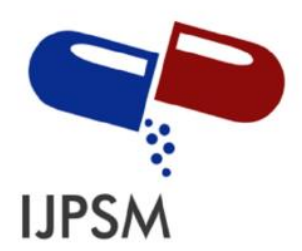

Manoj Kumar et al, Int. Journal of Pharmaceutical Sciences and Medicine (IJPSM), Vol.6 Issue. 1, January- 2021, pg. 51-74

ISSN: 2519-9889

Impact Factor: $\mathbf{3 . 4 2 6}$ diameter were punched into the agar medium and filled with $100 \mu \mathrm{l}$ of plant extract of $10 \mathrm{mg} / \mathrm{ml}$ concentration and solvent blank (DMSO) separately. The plates were incubated at $37^{\circ} \mathrm{C}$, over night. The antibiotic (chloramphenicol) at $100 \mu \mathrm{g} / \mathrm{ml}$ conc. was used in the test system as positive control. Zone of inhibition of bacterial growth around each well was measured in $\mathrm{mm}$.

\subsection{Minimum inhibitory concentration of plant extracts}

Minimum inhibitory concentration of plant extracts against test bacterial strains was determined by tube broth dilution method, using specific dye ( $p$-iodonitro tetrazolium violet) as an indicator of growth ${ }^{15} .2 \mathrm{ml}$ of the plant extract was mixed with $2 \mathrm{ml}$ of Muller-Hinton broth (Hi-Media Ltd., Mumbai, India) and serially diluted into the next tube and so on. $2 \mathrm{ml}$ of an actively growing culture of different test strains was added before incubating for over night, at $37{ }^{\circ} \mathrm{C}$. After examining turbidity visually, $0.8 \mathrm{ml}$ of $0.02 \mathrm{mg} / \mathrm{ml}$ indicator dye ( $\mathrm{p}$ iodonitro tetrazolium violet) was added to each tube and incubated at $37^{\circ} \mathrm{C}$. The tubes were examined for the colour development, after $30 \mathrm{~min}$. Absence of growth was also confirmed by spreading $0.1 \mathrm{ml}$ of broth from such test tube on normal nutrient agar plate.

\subsection{Synergistic interaction of plant extracts with antibiotics}

Synergistic interaction between antibiotics, like ampicillin, tetracycline and chloramphenicol with crude plant extracts was studied by agar well diffusion method. For determining the synergistic effects of plant extract with antibiotic, the wells were punched at a predetermined distances so that their inhibitory circles touch each other only tangentially without influencing each other as recommended ${ }^{10}$. The wells were inoculated with plant extract and antibiotic separately. Plates were then incubated at $37{ }^{\circ} \mathrm{C}$, for 18 hours. Enlargement of inhibition zones indicates a positive interaction (synergism). 


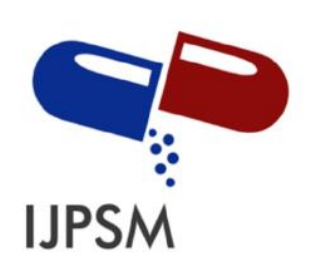

Manoj Kumar et al, Int. Journal of Pharmaceutical Sciences and Medicine (IJPSM), Vol.6 Issue. 1, January- 2021, pg. 51-74

ISSN: 2519-9889

Impact Factor: 3.426

\subsection{Phytochemical analysis of plant extracts}

Major phytocompounds, in the crude extracts of plants, were detected by standard colour tests, as described elsewhere ${ }^{21}$.

\subsection{Results and Discussion}

\subsection{Phytochemical Analysis}

Extracts obtained by continuous Soxhlet were subjected to qualitative phytochemical tests to identify the presence of secondary metabolite. The methanolic extract contained alkaloids, glycosides, tannins, flavonoids, sterols, fats, oils, phenols and saponins) present in them. as depicted in(Table 1).

\subsection{GC-MS results}

Gas liquid chromatogram of the methanolic extract of flowers of $S$. indicus revealed the presence of 5 peaks indicating the presence of 5 different compounds (Figure 1). The results revealed that $1,1,4,7$ tetramethyldecahydro-1H-cyclo $(65.94 \%)$ was the major component followed by 10-epigazaniotide (13.31\%), 7-isopropenyl-1,4s-dimethyl-4, 4a, 5,6,7,8 (12.56\%), Bohlmann k2631 (6.8\%), and 4-pregnene-3 beta, 20 beta-diol (1.39\%).

\subsection{The activity of $S$. indicus against dual-drug resistant strains of $H$. pylori}

Two strains of $H$. pylori were isolated from North Indian patient's biopsy sample, included in this study, and also found dual drug-resistant. Strain 1 showing dual drug resistance against Furazolidone and Cefixime and strain 2 was dual drug resistance against Levofloxacin and Cefixime.The study is in agreement of the work of Shweta Mahant et al\& Valentis Gehlot et al. $^{26,28,29,30}$

After incubation period under microaerophilic conditions, we found that only methanolic (MK6) extract and aqueous extract of $S$. indicus showed activity against both $H$. pylori dual drug-resistant strains. The aqueous extract showed activity against only one strain (Table-2). The MIC for one Dual drug-resistant strain of North India was 0.00015 gram for methanol 


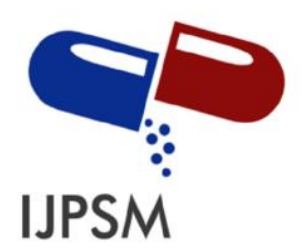

Manoj Kumar et al, Int. Journal of Pharmaceutical Sciences and Medicine (IJPSM), Vol.6 Issue. 1, January- 2021, pg. 51-74

ISSN: 2519-9889

Impact Factor: 3.426

and the second of the dual drug-resistant strain of North India was 0.01 gram for aqueous. The zone of inhibition was measured to be $8 \mathrm{~mm}$ and $6 \mathrm{~mm}$ for methanolic extract and 20 $\mathrm{mm}$ for aqueous extract of $\mathrm{S}$. indicus (Table 2 and Plate-1).

According to the data reported in plate-1, the flower extracts of the plant submitted to the screening test, produced inhibition zone diameters by the disk diffusion test. However, there is a disadvantage to this method in that it yields only qualitative results. The absence of objective quantification inherent in the method makes it impossible to compare the degree of antimicrobial activity of the extracts against the $H$. pylori strains investigated.The same work with different plants was reported by Shweta Mahant et al., 27,31,32,33,34

Anti-H. pylori activity of the flower extract of $S$. indicus has not been investigated earlier. Venkatachalam et $\mathrm{al}^{7}$ showed that leaf extract of S.indicus showed the activity against Staphylococcus faecalis and S. aureus.

A bicyclic sesquiterpene lactone isolated from the petroleum ether extract of the aerial part of the S. indicus was reported to have antimicrobial activity against Staph. aureus, Escherichia coli, Fusarium sp., Helminthosporium sp. and other microorganisms. ${ }^{8}$ Antimicrobial activity of alkaloidal and nonalkaloidal fractions of alcoholic extract of flowers has also been reported. ${ }^{9}$

\subsection{Antimicrobial activity of S.indicus against drug resistance human pathogenic bacteria}

Multiple drug resistance in pathogenic bacteria has emerged as important problem in many countries of the world. There are now increasing case reports documenting the development of clinical resistance to newer and broad spectrum antibacterial drugs like fluroquinolone (norfloxacin, ciprofloxacin, oflaxacin etc.) in many pathogenic bacteria. In the present study, clinical isolates of $S$. aureus $P$. aeruginosa, Shigella spp. E. coli, Citrobacter spp., B. subtilis and Candida albicans were used. These microbial strains are found to be resistant to one or more antibiotics, showing the common occurrence of drug resistance. These finding are in 


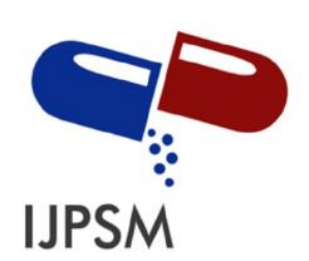

Manoj Kumar et al, Int. Journal of Pharmaceutical Sciences and Medicine (IJPSM), Vol.6 Issue. 1, January- 2021, pg. 51-74

ISSN: 2519-9889

Impact Factor: 3.426

agreement with the reports of previous workers as these strains have been previously tested for their sensitivity to antibiotics ${ }^{21},{ }^{22,16},{ }^{23}$. Further these test isolates of bacteria were also tested for the production of $\beta$-lactamases (Table 7)

The details of collected plant material of S.indicus, their ethanobotanical data and parts used have been given in the Table 3. Antibacterial activity of crude extracts of S.indicus against Gram positive bacteria ( 7 distinct isolates of $S$. aureus and $B$. subtilis) and Gram- negative bacteria (E.coli, P. aeruginosa, Citrobacter and Shigella spp.) and a yeast (C. albicans) is presented in Table 4 and 5 . Activity of methanolic curde extracts against Gram positive bacteria showed strong activity(Table 4). On the other hand broad spectrum activity against Gram negative MDR bacteria was exhibited by S.indicus as evidenced from their activity against more than 3 test bacteria with fair size of zone of inhibition (Table 5). Similarly anticandidal activity of S.indicus extracts as demonstrated in (Table 5) and highest activity in terms of radius of zone of inhibition was recorded. Over all sensitivity of MDR bacteria against S.indicus extracts showed that $P$. aeruginosa strain is more sensitive followed by S. aureus, P. aeruginosa, B. subtilis, Shigella spp. and E. coli.

S.indicus plant extracts was also evaluated for their potency in terms of minimum inhibitory concentration against a variety of MDR bacteria as shown in table 6. MIC values varied greatly from $0.51 \mathrm{mg} / \mathrm{ml}$ to $4.62 \mathrm{mg} / \mathrm{ml}$ against test bacteria. Variation in MIC values might be due to difference in cell well composition and intrinsic tolerance of the test isolates, nature and composition of phytoconstituents.

Phytochemcial analysis of S.indicus plant extracts was made for the presence of major phytocompounds like alkaloids, flavonoides glycoside, phenols \& tannins as depicted in Table 1. The differences in their phytocompounds might be responsible for varied activity \& MIC values. Thus our antimicrobial screening results also justify the traditional uses of this plant in ailments and localized skin infections caused by S.aureus, E.coli, Shigella spp., P.aeruginosa, and Candida albicans. 


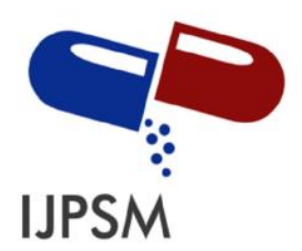

Manoj Kumar et al, Int. Journal of Pharmaceutical Sciences and Medicine (IJPSM), Vol.6 Issue. 1, January- 2021, pg. 51-74

ISSN: 2519-9889

Impact Factor: 3.426

\section{Synergism in plant extracts}

In the traditional system of medicine (Ayurveda and Unani-Tibbiya) formulation of herbal drugs are prepared as a mixture of many crude extracts in different preparations. It is commonly believed that various active phytoconstituents of plant extracts posses additive or synergistic activity. Therefore, S.indicus was selected on the basis of their antimicrobial activity against $S$. aureus and was also tested in different combinations by agar well diffusion method (table 8). Significant activity was detected in different extract combination The synergism in some of the above interaction is shown in plate 2 .

This preliminary investigation suggested that it would be wise to evaluate the possible additive, synergistic or antagonistic interaction of crude plant extracts in different combinations to obtain enhanced activity of herbal preparations. Although, it will also require an additional data on in vivo studies.

Multiple antibiotic therapy is now considered an effective way to control infectious diseases caused by drug resistant bacteria. Phytocompounds which may have strong activity against antibiotic resistant bacteria is expected to give strong synergistic and additive effect with antibiotics. Considering this known fact we have tried to see the possible synergistic effect between S.indicus extracts and antibiotics. This plant extract showed synergistic interaction with tetracycline, chloramphenicol, ampicillin and gentamycin against mutlidrug resistant $S$. aureus (MRSA) strain. The above findings show that synergistic interactions are specific and the possible reason may be found in the interaction of different phytoconstituents with antibiotics. This result agrees with the observation of synergistic interactions of medicinal plants with chloramphenicol as reported ${ }^{22}$. 


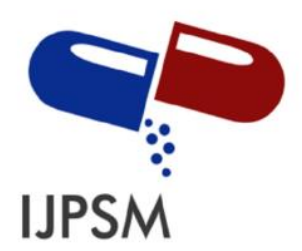

Manoj Kumar et al, Int. Journal of Pharmaceutical Sciences and Medicine (IJPSM), Vol.6 Issue. 1, January- 2021, pg. 51-74

ISSN: 2519-9889

Impact Factor: 3.426

\subsection{Conclusion}

Results demonstrate that the flower extract of $S$. indicus is capable of inhibiting the in vitro growth of $\mathrm{H}$. pylori and could form a promising basis for further investigation in the discovery of new natural anti-H. pylori compounds.

This preliminary investigation also indicated that potential plant extracts of S.indicus showing broad spectrum antimicrobial activity and synergy could be further tested to determine the efficacy in vivo against MDR bacteria. Active fractions of this plants may also be exploited in preparation of herbal formulation of improved efficacy and quality.

\section{References}

1. Kusters JG, Van Vliet AH,Kuipers EJ. Pathogenesis of Helicobacter pylori infection. Clin Microbiol Rev.2006;19:449-490

2. Mégraud F, Lehours P. Helicobacter pylori detection and antimicrobial susceptibility testing. Clin Microbiol Rev. 2007;20:280-322.

3. Gadhi CA, Benharref A, Jana M, Lozniewski A. Anti-Helicobacter pylori activity of AristolochiapaucinervisPomel extracts. J Ethnopharmacol. 2001;75:203-205.

4. Nostro A, Cellini L, Di Bartolomeo S, Di Campli E, Grande R, Cannatelli MA, et al. Antibacterial effect of plant extracts against Helicobacter pylori. Phytother Res. 2005;19:198-202.

5. 5. Kirtikar KR, Basu BD, ICS. Indian medicinal plants. In: Blatter E, Caius JF, Mhaskar KS, editors. 2nd ed. Vol-2. Allahabad India: Lalit Mohan Basu; 1981. pp. 1346-8

6. Chatterjee A, Pakrashi SC. 1st ed. Vol-5. New Delhi: National Institute of Science communication and information resources; 2003. The treatise on Indian medicinal plants; p. 177

7. Venkatachalam D, Thavamani SB, Muddukrishniah K. Antimicrobial activity of leaf of Sphaeranthus indicus against some selected human pathogenic bacteria. Journal of medical Pharmaceutical and allied sciences. 2018;754:1008-1016

8. Singh SK, Saroj KM, Tripathi VJ, Singh AK, Singh RH. An Antimicrobial Principle from Sphaeranthus indicus L.(Family Compositae) Int J Crude Drug Res. 1988;26:235-9. 


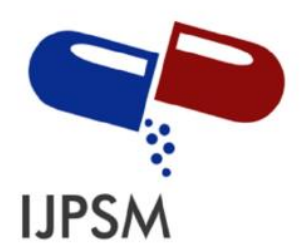

Manoj Kumar et al, Int. Journal of Pharmaceutical Sciences and Medicine (IJPSM), Vol.6 Issue. 1, January- 2021, pg. 51-74

ISSN: 2519-9889

Impact Factor: 3.426

9. Shaikh D, Naqui BS, Shaikh R. The antimicrobial principles of Sphaeranthus indicus: Isolation, purification and antimicrobial action. Pak J Scientific Ind Res. 1986;29:36671

10.0. Ahmad, I; Zahin M, Aqil F, Hasan S, Khan, MSA and Owais M (2008): Bioactive compounds from Punica granatum, Curcuma longa, and Zingiber Officinale and their therapeutic potential (Review). Drug of the Future 33(4): 01-18.

11.0. Liu, X. I.; Durham, D.G. and Richards, R.M.E. (2000). Baicalin synergy with $\beta$ lactam antibiotics against methicillin resistant staphylococcus aureus and other $\beta$-lactam-resistant strains of S. aureus. J. Pharm. Pharmacol. 52: 361.

12.0. Edelstein, M.; Pimkin, M. Edelstein, I; Drithachenko, T; Semenov, V; Stratchounslei, L., (2001). Clonal spread of Cefotaxime-Resistant. $41^{\text {st }}$ Interscience Conference on Antimicrobial Agents and Chemotherapy.

13.0. Tonkic, M., Goic-Barisic, I; Punda-Polic, V, (2005). Prevalence and antimicrobial resistance of extended spectrum of extended spectrum of $\beta$ lactamases producing $E$. coli and $K$. pneumoniae strains isolated in a university hospital, split, croatia. Int. Microbial 8 (2): 119-24.

14.0. World Health Organization (1993). Summary of WHO guide lines for the assessments of herbal medicines. Herbal Gram 28: 13-14.

15.0. Eloff, J.N. (1998). Which extract should be used for the screening and isolation of antimicrobial components from plants. J. of Ethanopharm 60: 1-8.

16.0. Aqil F and Iqbal Ahmad (2007): Antibacterial properties of traditionally used Indian medicinal plants. Methods \& Finding Experim. Clin. Pharmacol.. 29(2): 79-92.

17.0. Chopra, R.N.; Nayer, S.L. and Chopra, I.C. (1992). Glossary of Indian medicinal plants ( $3^{\text {rd }}$ Edn.) Council of Scientific and industrial research New-Delhi (India): 246-7.

18.0. Ahmad, I; Mehmood, Z. and Mohammad, F. (1998). Screening of same Indian medicinal plants for their antimicrobial properties. J. of Ethanopharma. 62: 183-193. 


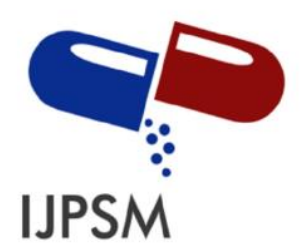

Manoj Kumar et al, Int. Journal of Pharmaceutical Sciences and Medicine (IJPSM), Vol.6 Issue. 1, January- 2021, pg. 51-74

ISSN: 2519-9889

Impact Factor: 3.426

19.0. Mehmood, Z.; Ahmad, I.; Mohammad, F. and Ahmad S. (1999). Indian Medicinal Plants: A potential source for anticandidal drugs. Pharm. Biol. 37 (3): 237-242.

20.0. Bauer, A.W.; Kirby, W.M.M.; Sherris, J.C and Turch M. (1966). Antibiotic susceptibility testing by standardized single disc method. AM. J. Clini. pathol. 45: 493-496.

21.0. Ahmad, I. and Beg, A.Z. (2001). Antimicrobial and Phytochemical studies on 45 Indian medicinal plants against multidrug resistant human pathogens. J. of Ethanopharma. 74: 113-123.

22.0. Aqil, F., Khan, MSA, Owais, M. and Iqbal Ahamd (2005): Effect of certain bioactive plant extracts on clinical isolates of $\beta$-lactamase producing methicillin resistant Staphylococcus aureus. J. Basic Microbiol.. 45: 106-114.

23.0. Jafri,H; Husain, F.M.; Ahmad, I. (2014) Antibacterial and antibiofilm activity of some essential oils and compounds against clinical strains of Staphylococcus aureus. J.biomed.ther.sci. 1(1):65-71

24.0. Ramachandran Shakila(2013) Review on Sphaeranthus indicus Pharmacognosy Reviews(7)14,157-169.

25.0. Perez, C.; Pauli, M. and Bazerque, P. (1990). An antibiotic assay by well diffusion method. Acta. Bioloziae et Med. Exper. 15: 113-115.

26. Shweta Mahant, Amresh Kumar Sharma, Valentina Gehlot, Asish Kumar Mukhopadhyay, Ayushi Chhawchharia, Sangitanjan Dutta, Anil Agarwal, Anup Som, Kunal Das, Rajashree Das. Geographically distinct North-East Indian Helicobacterpylori strains are highly sensitive to Clarithromycin but are Levofloxacin resistant. Indian Journal of Medical Microbiology., 2019; 37:337-44.

27. Shweta Mahant, Valentina Gehlot, Seema Bhatnagar, Megha Rikhi, Asish Kumar Mukhopadhyay, Sangitanjan Dutta, Anil Agarwal, Kunal Das, Rajashree Das. Antibiogram profiling of Helicobacter pylori strains and the efficacy of Brassica 


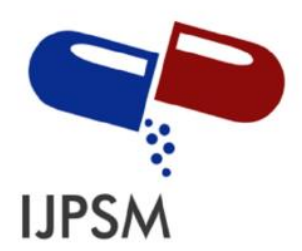

Manoj Kumar et al, Int. Journal of Pharmaceutical Sciences and Medicine (IJPSM), Vol.6 Issue. 1, January- 2021, pg. 51-74

ISSN: 2519-9889

Impact Factor: 3.426

capitata against resistant strains isolated from the patients suffering from gastroduodenal diseases in Guwahati, Assam. Asian Journal of Pharmaceutical and Clinical Research., 2018; 11 (8)76-180. ISSN: 2455-3891. Impact factor-0.7

28. Valentina Gehlot, Shweta Mahant, Asish Kumar Mukhopadhyay, Kunal Das, Jawed Alam, Prachetash Ghosh, Rajashree Das. Low prevalence of clarithromycin-resistant Helicobacter pylori isolates with A2143G point mutation in the 23S rRNA gene in North India. Journal of Global Antimicrobial resistance. 2016; 6, 39-43. Impact Factor2.5, Citation-3, ISSN: 2213-7165.

29. Valentina Gehlot, Shweta Mahant, , Kunal Das, Rajashree Das. Most of the Helicobacter pylori isolates are resistant to levofloxacin in North India. International Journal of Pharmacy and Pharmaceutical Sciences 2016; 8(1) 454-456. ISSN - 0975 1491.

30. Valentina Gehlot, Shweta Mahant, Asish Kumar Mukhopadhyay, Kunal Das, Ronita De, Premashis Kar, Rajashree Das. Antimicrobial susceptibility profiles of Helicobacter pylori isolated from patients in North India. Journal of Global Antimicrobial resistance 2016; 5, 51-56. Citation 3, Impact factor- 2.5.

31. Saumya Das, Manas Kumar Das, Rajashree Das, Valentina Gehlot, Shweta Mahant, Papiya Mitra Mazumder, Sanjita Das, Neha Fallse, Vikas Kumare. Isolation, characterization of Berberine from Berberis aristata DC for eradication of resistant Helicobacter pylori. Biocatalysis and Agricultural Biotechnology. Volume 26, July 2020, 101622. Impact Factor-0.9. DOI-https://doi.org/10.1016/j.bcab.2020.101622

32. Valentina Gehlot, Shweta Mahant, Pooja Vijayraghwan, Kunal Das, Shanu Hoda, Rajashree Das. Therapeutic potential of lichen Parmelia perlata against the dual drug resistant Helicobacter pylori. International Journal of Pharmacy and Pharmaceutical Sciences 2016; 8(1). Citation 4. Impact Factor- 0.5, ISSN - 0975 - 149

33. Silpi Chanda, Valentina Gehlot, Rajashree Das, Shweta Mahant, Kunal Das, Kuldeep Singh, Sayeed Ahmad. Antimicrobial activity of herbal extract against drug resistant 


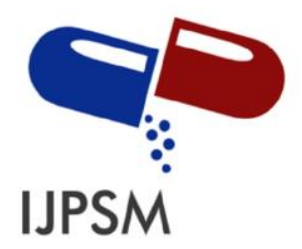

Manoj Kumar et al, Int. Journal of Pharmaceutical Sciences and Medicine (IJPSM), Vol.6 Issue. 1, January- 2021, pg. 51-74

ISSN: 2519-9889

Impact Factor: 3.426

H. pylori isolated from India. 2014. World Journal of Pharmaceutical Research. Vol. 3, Issue 4.

34. Mehrotra, S., R. Jamwal, R. Shyam, D. K. Meena, K. Mishra, R. Patra, R. De, A.K. Mukhopadhyay, A.K. Srivastava, S. Paul Nandi. 2011. Anti-Helicobacter pylori and antioxidant properties of Emblica officinalis pulp extract; a potential source for therapeutic use against gastric ulcer. J Med Plants Res. 5(12):2577-2583. Citation:16.

\section{Table, Figures and Plates}

Table 2: Zone of inhibition

\begin{tabular}{|c|c|c|c|c|c|}
\hline \multirow[t]{2}{*}{ Strains nos. } & \multirow{2}{*}{$\begin{array}{l}\text { MIC for } \\
\text { (agar } \\
\text { dilution } \\
\text { method) }\end{array}$} & \multicolumn{2}{|c|}{$\begin{array}{c}\text { Methanolic extract of (by disc } \\
\text { diffusion extract) }\end{array}$} & \multicolumn{2}{|c|}{$\begin{array}{l}\text { Aqueous extract of (by } \\
\text { agar well diffusion } \\
\text { method) }\end{array}$} \\
\hline & & $\begin{array}{l}\text { Zone of } \\
\text { inhibition }\end{array}$ & $\begin{array}{l}\text { Conc. (in } \\
\mathrm{mg} \text { ) }\end{array}$ & $\begin{array}{l}\text { Zone of } \\
\text { inhibition }\end{array}$ & $\begin{array}{l}\text { Conc. (in } \\
\mu g \text { ) }\end{array}$ \\
\hline 394 & $\begin{array}{l}\mathrm{CIFI}= \\
0.001 \mathrm{mg}, \\
\text { FURA = } \\
0.002 \mathrm{mg}\end{array}$ & $8 \mathrm{~mm}$ & $0.15 \mathrm{mg}$ & $20 \mathrm{~mm}$ & $10 \mathrm{mg}$ \\
\hline 399 & $\begin{array}{l}\mathrm{CIFI}= \\
0.001 \mathrm{mg}, \\
\mathrm{LEVO}= \\
0.002 \mathrm{mg}\end{array}$ & $6 \mathrm{~mm}$ & $0.15 \mathrm{mg}$ & None & $10 \mathrm{mg}$ \\
\hline
\end{tabular}




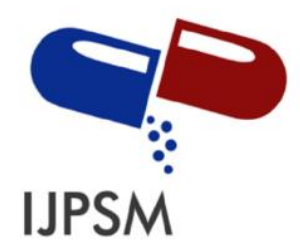

Manoj Kumar et al, Int. Journal of Pharmaceutical Sciences and Medicine (IJPSM), Vol.6 Issue. 1, January- 2021, pg. 51-74

ISSN: 2519-9889

Impact Factor: 3.426

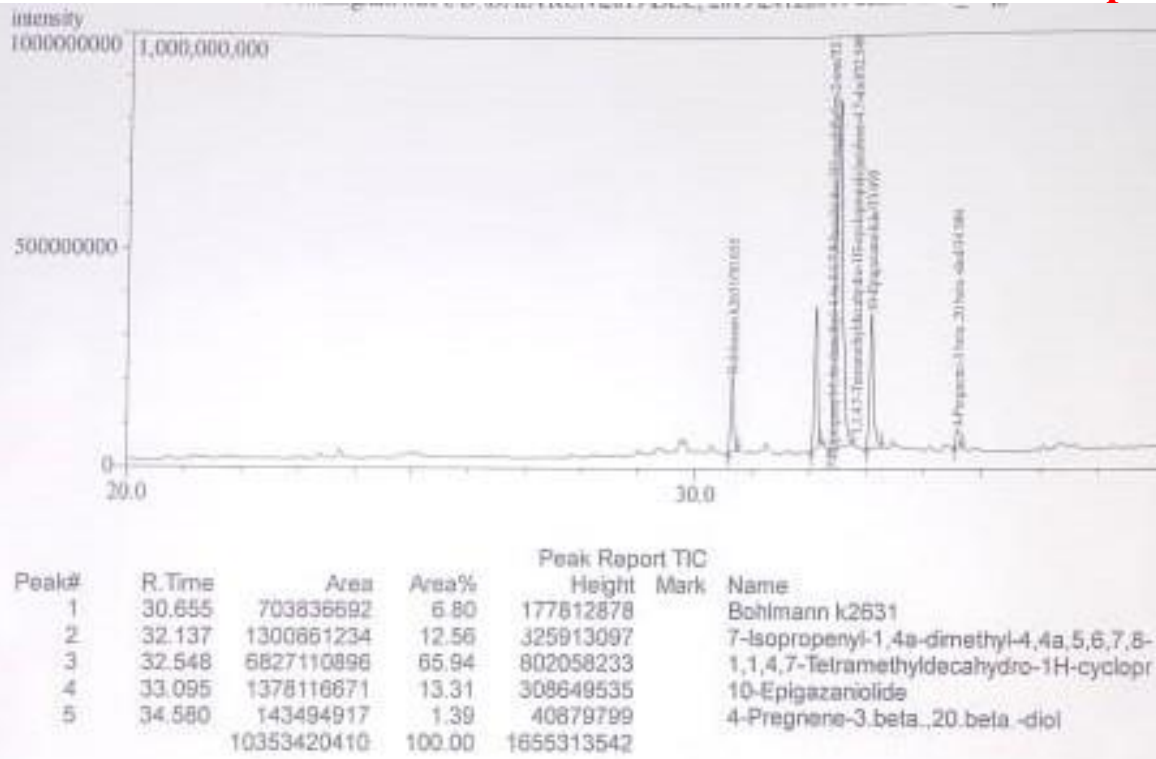

Figure 1: GC-MS of methanolic extract of flowers of S. indicus.

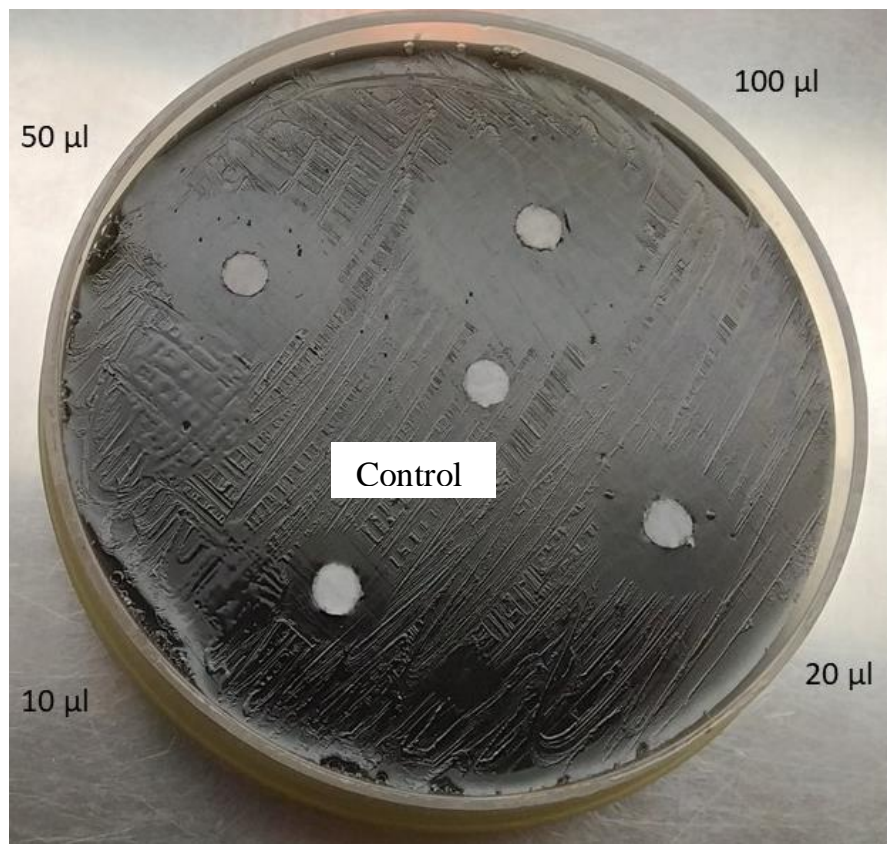

Plate-1: Antimicrobial activity of S.indicus against H.pylori 


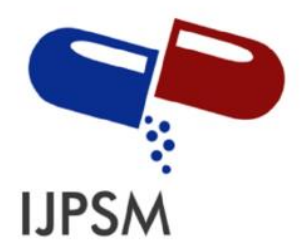

Manoj Kumar et al, Int. Journal of Pharmaceutical Sciences and Medicine (IJPSM), Vol.6 Issue. 1, January- 2021, pg. 51-74

ISSN: 2519-9889

Impact Factor: 3.426

Table 7.Antibiotics resistant pattern and $\beta$-lactamase production by test strains

\begin{tabular}{|c|c|c|c|c|}
\hline \multirow[t]{2}{*}{$\begin{array}{l}\text { Name of } \\
\text { bacteria }\end{array}$} & \multirow[t]{2}{*}{ Strains code } & \multicolumn{2}{|c|}{$\begin{array}{l}\beta \text {-lactamase hydrolyzing } \\
\beta \text {-lactam antibiotics }\end{array}$} & \multirow[t]{2}{*}{$\begin{array}{l}\text { Resistant pattern of used } \\
\text { strains against antibiotics }\end{array}$} \\
\hline & & Ampicillin & $\begin{array}{l}\text { Benzyl } \\
\text { Ipenicillin }\end{array}$ & \\
\hline $\begin{array}{l}\text { Staphylococcus } \\
\text { aureus }\end{array}$ & SA-03 & + & + & $\mathrm{Cx}, \mathrm{M}, \mathrm{A} . \mathrm{Pn}, \mathrm{Cf}, \mathrm{Do}, \mathrm{Sm}, \mathrm{Na}$ \\
\hline $\begin{array}{l}\text { Staphylococcus } \\
\text { aureus }\end{array}$ & SA-08 & - & - & $\mathrm{Cx}, \mathrm{M}, \mathrm{A}, \mathrm{Pn}, \mathrm{Cf}, \mathrm{Sm}$ \\
\hline $\begin{array}{l}\text { Staphylococcus } \\
\text { aureus }\end{array}$ & SA-11 & + & + & $\mathrm{Pn}, \mathrm{Am}, \mathrm{M}, \mathrm{S}, \mathrm{T}, \mathrm{Do}, \mathrm{Na}, \mathrm{Cu}$ \\
\hline $\begin{array}{l}\text { Staphylococcus } \\
\text { aureus }\end{array}$ & SA-21 & + & + & $C x, M, A, P n, C f, D o, S m$ \\
\hline $\begin{array}{l}\text { Staphylococcus } \\
\text { aureus }\end{array}$ & SA-22 & + & + & Sensitive to all drugs \\
\hline $\begin{array}{l}\text { Staphylococcus } \\
\text { aureus }\end{array}$ & SA-28 & + & + & $\mathrm{Pn}, \mathrm{Am}, \mathrm{Cx}, \mathrm{Cf}, \mathrm{M}, \mathrm{Pc}, \mathrm{Kt}, \mathrm{T}, \mathrm{S}$, \\
\hline $\begin{array}{l}\text { Staphylococcus } \\
\text { aureus }\end{array}$ & SA-29 & + & + & $C x, M, A, P$ \\
\hline
\end{tabular}




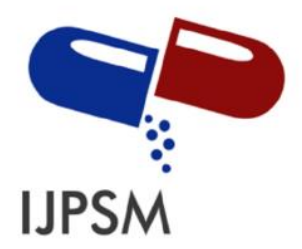

Manoj Kumar et al, Int. Journal of Pharmaceutical Sciences and Medicine (IJPSM), Vol.6 Issue. 1, January- 2021, pg. 51-74

ISSN: 2519-9889

Impact Factor: 3.426

\begin{tabular}{|c|c|c|c|c|}
\hline E.coli & UP-2556 & - & - & $P n, A, C x, D o$ \\
\hline E.coli & EC-14 & + & + & $\mathrm{Pn}, \mathrm{A}, \mathrm{Cx}, \mathrm{M}, \mathrm{Ce}, \mathrm{Cfx}, \mathrm{Cep}, \mathrm{Cu}$, \\
\hline E.coli & $\mathrm{EC}-20$ & + & + & $\begin{array}{l}\mathrm{Pn}, \mathrm{A}, \mathrm{Cx}, \mathrm{M}, \mathrm{Ce}, \mathrm{Cfx}, \mathrm{Cu}, \mathrm{Va}, \mathrm{T}, \\
\mathrm{E},\end{array}$ \\
\hline Citrobacter $s p$ & SM-06 & + & + & $\begin{array}{l}\mathrm{Pn}, \mathrm{A}, \mathrm{Cx}, \mathrm{M}, \mathrm{Co}, \mathrm{T}, \mathrm{C}, \mathrm{Do}, \mathrm{Nx} \\
\mathrm{Nf}, \mathrm{Na}, \mathrm{Cu}\end{array}$ \\
\hline Shigella $s p$. & SM-07 & + & + & $\mathrm{Pn}, \mathrm{Cx}, \mathrm{M}, \mathrm{Co}, \mathrm{Cf}, \mathrm{T}$ Do C, Na \\
\hline Shigella sp. & SM-08 & + & + & $\mathrm{Pn}, \mathrm{A}, \mathrm{Cx}, \mathrm{Co}, \mathrm{Ce}, \mathrm{Cf}, \mathrm{Cfxx}, \mathrm{Na}$ \\
\hline Citrobacter $s p$ & $\mathrm{EN}-06$ & + & + & $\mathrm{Pn}, \mathrm{Cx}, \mathrm{M}, \mathrm{T}, \mathrm{C}, \mathrm{Do}, \mathrm{Nx}, \mathrm{Na}, \mathrm{E}$ \\
\hline P. aeruginosa & P.aeruginosa & NT & NT & $\mathrm{A}, \mathrm{C}, \mathrm{T}, \mathrm{Na}, \mathrm{Co}, \mathrm{Cx}, \mathrm{Am}, \mathrm{M}$ \\
\hline B. subtilis & BS & - & - & Sensitive \\
\hline
\end{tabular}

Pn, Penicillin, A, Ampicillin; Cx, Cloxacillin, Ce, Cephotaxime; $\mathrm{Cu}$, Cefuroxime; $\mathrm{Cfx}$, Cefixime, Cefpodoxime; $\mathrm{M}$, Methicillin; Va, Vancomycin; Nf, Nitrofurantoin, Nx, Norfloxacin, Nv, Novobiocin Co, Co-trimoxazole; Na, Nalidixic acid; T, Tetracyline; C, Chloramphenicol; Do, Doxycycline; E, Erthromycin. 


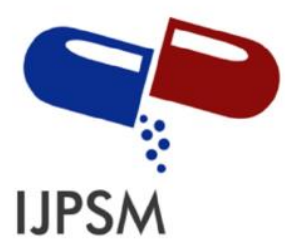

Manoj Kumar et al, Int. Journal of Pharmaceutical Sciences and Medicine (IJPSM),

Vol.6 Issue. 1, January- 2021, pg. 51-74

ISSN: 2519-9889

Impact Factor: 3.426

Table 3 Ethanobotanical data and traditional uses of medicinal plants.

\begin{tabular}{|c|c|c|c|c|c|c|}
\hline S. No. & $\begin{array}{l}\text { Scientific Name } \\
\text { (Family) } \\
\text { V-Sp.-No. }\end{array}$ & $\begin{array}{l}\text { Vernacula } \\
\text { r name }\end{array}$ & $\begin{array}{l}\text { Part } \\
\text { Used }\end{array}$ & $\begin{array}{l}\text { Site of } \\
\text { Collection }\end{array}$ & $\begin{array}{l}\text { Known } \\
\text { Phytocompounds }\end{array}$ & $\begin{array}{l}\text { Traditional } \\
\text { Uses }\end{array}$ \\
\hline 1 & $\begin{array}{l}\text { Sphaeranthus } \\
\text { indicus Linn } \\
\text { (Asteraceae) } \\
\text { PTA-76/02 }\end{array}$ & Mundi & flowers & $\begin{array}{l}\text { Haridwar } \\
\text { Uttarakhan } \\
\text { d } \\
\text { India }\end{array}$ & $\begin{array}{l}\text { Eudesmanolides } \\
\text { Sesquiterpenoids } \\
\text { Sesquiterpene } \\
\text { lactones } \\
\text { Flavone } \\
\text { glycosides } \\
\text { Flavonoids-C- } \\
\text { Glycosides } \\
\text { Sterols,alkaloids,a } \\
\text { mino acids } \\
\text { And } \\
\text { sugars(R.Shakila,2 } \\
013)^{24}\end{array}$ & $\begin{array}{l}\text { Used in } \\
\text { wound } \\
\text { healing, } \\
\text { Analgesics, he } \\
\text { patoprotectiv } \\
\text { e,bronchodila } \\
\text { tory,antioxid } \\
\text { ants,Psoriasis } \\
(\text { R.Shakila,20 } \\
\text { (3) }\end{array}$ \\
\hline
\end{tabular}

Table 4 Antibacterial activity of plant extracts against Gram positive bacteria

\begin{tabular}{|c|c|c|c|c|c|c|c|c|c|c|}
\hline \multirow{2}{*}{$\begin{array}{l}\text { S. } \\
\text { No }\end{array}$} & \multirow{2}{*}{$\begin{array}{l}\text { Scientific } \\
\text { Name } \\
\text { (Family) }\end{array}$} & \multirow{2}{*}{$\begin{array}{c}\text { Percent } \\
\text { Yield }\end{array}$} & \multicolumn{8}{|c|}{ Antimicrobial activity (Radius in $\mathrm{mm}) \pm \mathrm{SD}$} \\
\hline & & & SA-03 & SA-08 & SA-11 & SA-21 & SA-22 & SA-28 & SA-29 & $\begin{array}{l}\text { MTCC } \\
121 *\end{array}$ \\
\hline & S.indicus & 10.20 & $\begin{array}{c}9.20 \\
\pm 0.12\end{array}$ & $\begin{array}{c}8.23 \\
\pm 0.25\end{array}$ & $\begin{array}{l}10.23 \\
\pm 0.25\end{array}$ & - & $\begin{array}{c}8.33 \\
\pm 0.28\end{array}$ & $\begin{array}{c}6.33 \pm \\
0.28\end{array}$ & $\begin{array}{c}8.33 \\
\pm 0.28\end{array}$ & - \\
\hline
\end{tabular}

* MTCC 121, Bacillus subtilis, SD - Standard deviation 


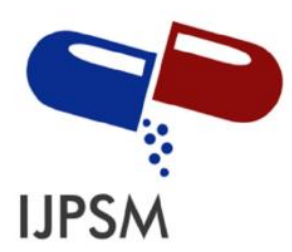

Manoj Kumar et al, Int. Journal of Pharmaceutical Sciences and Medicine (IJPSM), Vol.6 Issue. 1, January- 2021, pg. 51-74

ISSN: 2519-9889

Impact Factor: 3.426

Table 5 Antibacterial activity of plant extracts against Gram negative bacteria

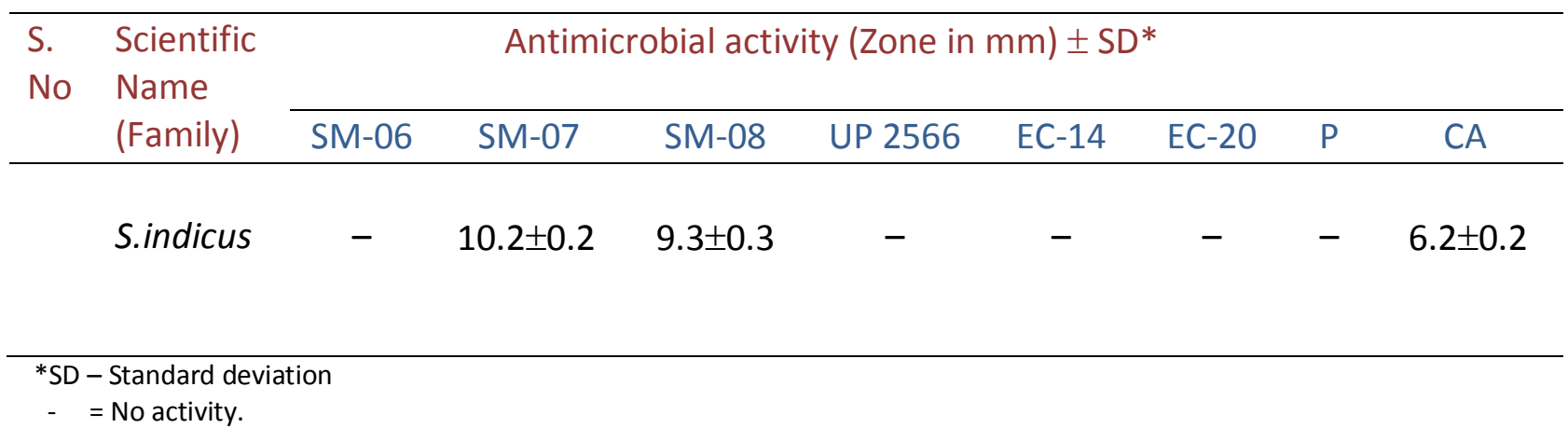

Table No. 6 Activity profile of crude plant extracts in terms of Minimum inhibitory concentration (MIC)

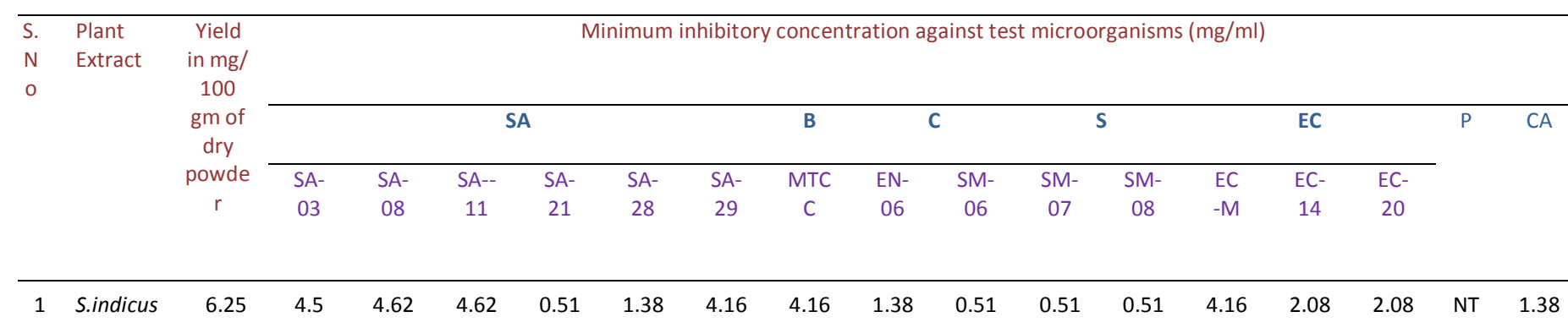

NT - Not tested.

Organisms key: SA - Staphylococcus aureus, B-Bacillus subtilis, C - Citrobacter spp., S-Shigella spp., EC

- E.coli, P-Pseudomonas aeruginosa, CA-Candida albicans .

Table 1- Phytochemical analysis of active plant extracts for major bioactive compounds

\begin{tabular}{|c|c|c|c|c|c|c|c|c|}
\hline \multirow[t]{3}{*}{ S. no. } & \multirow{3}{*}{$\begin{array}{l}\text { Plant } \\
\text { name }\end{array}$} & \multirow{3}{*}{$\begin{array}{l}\text { Part } \\
\text { used }\end{array}$} & \multicolumn{6}{|c|}{ Phytocompounds detected } \\
\hline & & & \multirow[t]{2}{*}{ Alkaloids } & \multirow[t]{2}{*}{ Flavonoids } & \multirow[t]{2}{*}{ Glycosides } & \multirow[t]{2}{*}{ Phenols } & \multicolumn{2}{|c|}{ Tannins } \\
\hline & & & & & & & Epi/gallo & $\begin{array}{c}\text { Condense } \\
\text { d salts }\end{array}$ \\
\hline & S.indicus & Fruit & + & + & + & - & - & - \\
\hline
\end{tabular}




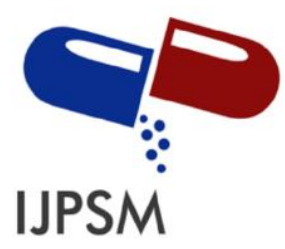

Manoj Kumar et al, Int. Journal of Pharmaceutical Sciences and Medicine (IJPSM),

Vol.6 Issue. 1, January- 2021, pg. 51-74

ISSN: 2519-9889

Impact Factor: 3.426

Table 8 Synergistic interaction between Plant extract and antibiotics

\begin{tabular}{|c|c|c|c|c|c|c|c|}
\hline $\begin{array}{l}\text { Strains } \\
\text { Used }\end{array}$ & $\begin{array}{c}\text { Plant } \\
\text { extract } \\
(P)\end{array}$ & $\begin{array}{c}r_{\mathrm{p}} \\
(\text { in } \mathrm{mm})\end{array}$ & $\begin{array}{l}\text { Antibiotic } \\
\text { (A) }\end{array}$ & $\begin{array}{c}\mathrm{r}_{\mathrm{A}} \\
(\mathrm{in} \mathrm{mm})\end{array}$ & $\begin{array}{l}\text { Combined } \\
\text { radius }\left(r_{P}+\right. \\
\left.r_{A}\right) \text { in } m m \\
\end{array}$ & $\begin{array}{c}\text { Enlargement } \\
\text { of Zone-size } \\
\text { (in } \mathrm{mm} \text { ) }\end{array}$ & Synergism \\
\hline \multirow{6}{*}{ SA-08 } & S. indicus & $7.0 \pm 0.8$ & $\mathrm{C}$ & $11.0 \pm 5$ & $23.1 \pm 0.5$ & 5 & + \\
\hline & S. indicus & $7.0 \pm 0.8$ & $\mathrm{~T}$ & $12.0 \pm 0.5$ & $19.1 \pm 0.3$ & - & - \\
\hline & S. indicus & $7.0 \pm 0.8$ & $\mathrm{Gm}$ & $12.0 \pm 0.5$ & $22.1 \pm 0.4$ & 3 & + \\
\hline & S. indicus & $7.0 \pm 0.8$ & $\mathrm{Am}$ & $10.1 \pm 1.0$ & $17.0 \pm 0.5$ & - & - \\
\hline & S. indicus & $7.0 \pm 0.8$ & $\mathrm{Na}$ & $10.0 \pm 0.3$ & $17.8 \pm 1.5$ & - & - \\
\hline & S. indicus & $7.0 \pm 0.8$ & $\mathrm{Cf}$ & $16.2 \pm 0.6$ & $23.8 \pm 0.6$ & - & - \\
\hline
\end{tabular}

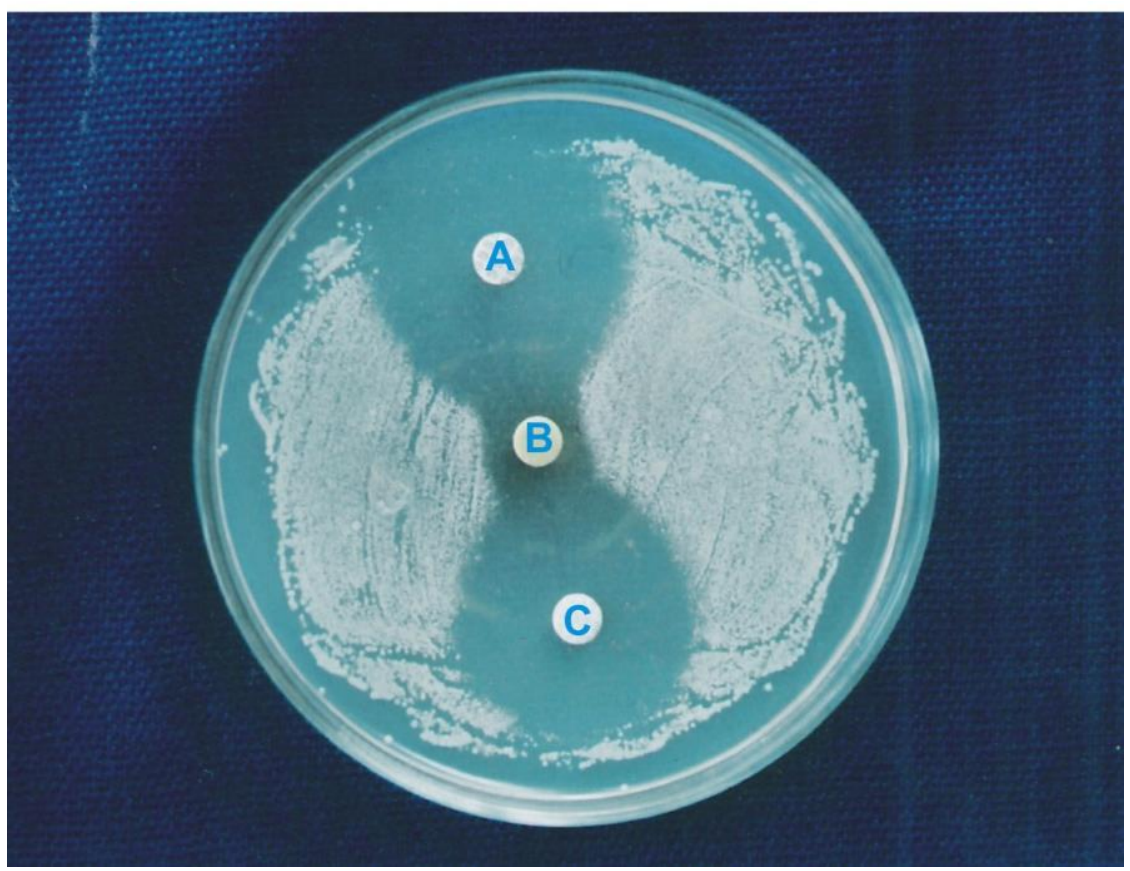

Plate 2 Synergistic interaction of plant extracts with antibiotics against S. aureus (SA-08)

(A) Gentamycin (B) Sphaeranthus indicus (C) Chloramphenicol 